\title{
The distributions of the six species constituting the smooth newt species complex (Lissotriton vulgaris sensu lato and L. montandoni) - an addition to the New Atlas of Amphibians and Reptiles of Europe
}

\author{
Ben Wielstra ${ }^{1,2,3, *}$, Daniele Canestrelli ${ }^{4}$, Milena Cvijanović ${ }^{5}$, Mathieu Denoël ${ }^{6}$, Anna Fijarczyk ${ }^{7,8}$, \\ Daniel Jablonski ${ }^{9}$, Marcin Liana ${ }^{10}$, Borislav Naumov ${ }^{11}$, Kurtuluş Olgun ${ }^{12}$, Maciej Pabijan ${ }^{13}$, \\ Alice Pezzarossa $^{4}$, Georgi Popgeorgiev ${ }^{14}$, Daniele Salvi ${ }^{15,16}$, Yali $\mathrm{Si}^{17,18}$, Neftalí Sillero ${ }^{19}$, \\ Konstantinos Sotiropoulos ${ }^{20}$, Piotr Zieliński ${ }^{7}$, Wiesław Babik ${ }^{7}$
}

\begin{abstract}
The 'smooth newt', the taxon traditionally referred to as Lissotriton vulgaris, consists of multiple morphologically distinct taxa. Given the uncertainty concerning the validity and rank of these taxa, $L$. vulgaris sensu lato has often been treated as a single, polytypic species. A recent study, driven by genetic data, proposed to recognize five species, $L$. graecus, L. kosswigi, L. lantzi, L. schmidtleri and a more restricted $L$. vulgaris. The Carpathian newt $L$. montandoni was confirmed to be a closely related sister species. We propose to refer to this collective of six Lissotriton species as the smooth newt or Lissotriton vulgaris species complex. Guided by comprehensive genomic data from throughout the range of the smooth newt species complex we 1) delineate the distribution ranges, 2) provide a distribution database, and 3) produce distribution maps according to the format of the New Atlas of Amphibians and Reptiles of Europe, for the six constituent species. This allows us to 4) highlight regions where more research is needed to determine the position of contact zones.
\end{abstract}

Keywords: Amphibian, contact zone, hybridization, range map, taxonomy, UTM grid.

1 - Department of Ecology and Evolutionary Biology, University of California, Los Angeles, CA 90095, USA

2 - Department of Animal and Plant Sciences, University of Sheffield, S10 2TN Sheffield, UK

3 - Naturalis Biodiversity Center, P.O. Box 9517, 2300 RA Leiden, The Netherlands

4 - Department of Ecological and Biological Science, Tuscia University, 01100 Viterbo, Italy

5 - Department of Evolutionary Biology, Institute for Biological Research "Siniša Stanković", University of Belgrade, Bul. Despota Stefana 142, 11060 Belgrade, Serbia

6 - Laboratory of Fish and Amphibian Ethology, Behavioural Biology Unit, Freshwater and OCeanic science Unit of reSearch (FOCUS), University of Liège, Liège, Belgium

7 - Institute of Environmental Sciences, Jagiellonian University, ul. Gronostajowa 7, 30-387 Kraków, Poland

8 - Institut de Biologie Intégrative et des Systèmes, Département de Biologie, PROTEO, Pavillon CharlesEugène-Marchand, Université Laval, Québec, QC, Canada

9 - Department of Zoology, Comenius University in Bratislava Mlynská dolina, Ilkovičova 6, 84215 Bratislava, Slovakia

10 - Obozowa 46, 30-060 Kraków, Poland
11 - Institute of Biodiversity and Ecosystem Research, Bulgarian Academy of Sciences, 2 Gagarin Street, 1113 Sofia, Bulgaria

12 - Department of Biology, Faculty of Arts and Sciences, Adnan Menderes University, 09010 Aydın, Turkey

13 - Department of Comparative Anatomy, Institute of Zoology and Biomedical Research, Jagiellonian University, ul. Gronostajowa 9, 30-387 Kraków, Poland

14 - National Museum of Natural History, Bulgarian Academy of Sciences, 1 Tsar Osvoboditel Blvd, 1000 Sofia, Bulgaria

15 - Department of Health, Life and Environmental Sciences, University of L'Aquila, Via Vetoio, 67100 Coppito, L'Aquila, Italy

16 - CIBIO-InBIO, Centro de Investigação em Biodiversidade e Recursos Genéticos, Universidade do Porto, Campus Agrário de Vairão, 4485-661 Vairão, Portugal

17 - Ministry of Education Key Laboratory for Earth System Modeling, and Department of Earth System Science, Tsinghua University, Beijing, China

18 - Center for Tropical Research, Institute of the Environment and Sustainability, University of California, Los Angeles, 621 Charles E. Yong Drive South, Los Angeles, CA 90095, USA

19 - CICGE - Centro de Investigação em Ciências GeoEspaciais, Observatório Astronómico Prof. Manuel de Downloaded from Brill.com04/26/2023 01:51:17PM 
One of the aims of the recently published New Atlas of Amphibians and Reptiles of Europe (Sillero et al., 2014a) is to identify gaps in the currently available knowledge on species distributions. Such knowledge gaps are particularly prevalent where taxonomic progress has resulted in the splitting of one species into several species with as yet poorly understood mutual range boundaries. A good example is the 'smooth newt', Lissotriton vulgaris sensu lato, which is often treated as a single, polytypic species (Schmidtler and Franzen, 2004) - as in the case of the New Atlas - but has been proposed to constitute multiple distinct species (Pabijan et al., 2017). The Carpathian newt, $L$. montandoni, is a close relative (Zavadil et al., 2003) and has its own map in the New Atlas. Because smooth and Carpathian newts are considerably more closely related to each other than to other Lissotriton species (Skorinov et al., 2008; Wiens et al., 2011; Pabijan et al., 2015, 2017), and because they have experienced periods of genetic exchange (Zieliński et al., 2013, 2016), we here support the proposal by Skorinov et al. (2011) to refer to the assemblage as a species complex: the smooth newt or Lissotriton vulgaris species complex. There has been disagreement in the literature concerning the validity and rank of the taxa comprising L. vulgaris sensu lato and the phylogenetic position of the Carpathian newt within the smooth newt species complex (Kalezić et al., 1987; Raxworthy, 1990; Krizmanić et al., 1997; Tuniyev, 1999; Dubois and Raffaëlli, 2009; Speybroeck et al., 2010; Frost, 2013; Wielstra et al., 2015). We briefly review previous attempts to delineate taxa before discussing a new taxonomy reflecting the latest insights gained from genomic data.

Barros, Alameda do Monte da Virgem, 4430-146 Vila Nova de Gaia, Portugal

20 - Department of Biological Applications and Technology, University of Ioannina, 45110 Ioannina, Greece

*Corresponding author;

e-mail: ben.wielstra@naturalis.nl
In the context of this new taxonomy we 1) delineate the distribution ranges, 2) provide a distribution database, and 3) produce distribution maps according to the New Atlas format for the constituent species of the smooth newt complex.

The taxa comprising the smooth newt species complex are distinguishable based on the male secondary sexual characters that develop during the annual aquatic breeding period (Zavadil et al., 2003; Schmidtler and Franzen, 2004). Morphological differences pertain to the presence/absence and extent of dorsal crests and tail fins, toe flaps, a tail filament, dorsolateral ridges and pigmentation patterns. Overall the morphological evidence points to narrow transition zones between some proposed taxa, while others show wider zones of intergradation (Schmidtler and Schmidtler, 1983; Krizmanić et al., 1997; Babik et al., 2003). Studies employing allozymes (Kalezić, 1984; Kalezić and Tucić, 1984; Kalezić et al., 1987; Rafiński et al., 2001; Skorinov et al., 2008) confirmed the genetic distinctiveness of some taxa but, due to the restricted geographical scope and difficulties in comparing allozyme results across studies, are of limited use to delineate taxa and their ranges at the scale of the entire species complex. The integration of DNA sequence data into smooth newt taxonomy has been hampered by the fact that the popular genetic marker mtDNA is highly misleading in this case. MtDNA shows extensive introgression between the different taxa and the original mtDNA of the Carpathian newt appears to have been completely replaced by smooth newt mtDNA (Babik et al., 2005; Nadachowska and Babik, 2009; Zieliński et al., 2013; Pabijan et al., 2015). Furthermore, not all mtDNA lineages correspond to morphologically defined taxa (Babik et al., 2005; Pabijan et al., 2015, 2017).

Genome-wide nuclear genetic data have the potential to provide an objective measure of species identity and a more reliable estimate of phylogeny. Recently, Pabijan et al. (2017) used sequences of 74 nuclear DNA markers (obtained with the protocol of Zieliński et al., 
2014b) for species delimitation, phylogenetic reconstruction, and inference of historical gene flow throughout the range of the smooth newt species complex. The authors recognize five $L$. vulgaris sensu lato species, for which vernacular names are proposed here: Greek smooth newt L. graecus (Wolterstorff, 1906), Kosswig's smooth newt L. kosswigi (Freytag, 1955), Caucasian smooth newt L. lantzi (Wolterstorff, 1914), Schmidtler's smooth newt L. schmidtleri (Raxworthy, 1988), and (a more strictly defined) northern smooth newt L. vulgaris (Linnaeus, 1758). Furthermore, Pabijan et al. (2017) confirm that the Carpathian newt L. montandoni (Boulenger, 1880) is not clustered within, but is the sister species of, the other members of the smooth newt species complex. Considering the extensive geographical and genomic sampling by Pabijan et al. (2017), we presume this taxonomical treatment reflects current knowledge based on multiple lines of evidence and is likely to be stable.

The geographical distribution of the six species constituting the smooth newt species complex is well understood in a broad sense (Zavadil et al., 2003; Schmidtler and Franzen, 2004). While the species L. kosswigi and $L$. lantzi are allopatrically distributed, the species L. graecus, L. schmidtleri and L. vulgaris meet in parapatry on the Balkan Peninsula. In the Carpathians the range of L. montandoni is fully enclosed by that of L. vulgaris and the two generally exclude each other by altitude (with L. montandoni taking over at higher elevations). Where the four species with parapatric ranges meet in nature, hybridization occurs to a smaller or greater extent, but the narrowness of the transition zones suggests substantial reproductive isolation (Babik et al., 2003, 2005; Nadachowska-Brzyska et al., 2012; Zieliński et al., 2014a; Pabijan et al., 2015, 2017). Pabijan et al. (2017) homed in on the contact zones between species and we here extend their sampling, filling in geographical regions previously poorly covered. We allocate population to species based on maximum likelihood estimation of individual ancestry, employing single nucleotide polymorphisms (SNPs), obtained with the protocol of Niedzicka et al. (2016), using the program ADMIXTURE 1.3.0 (Alexander et al., 2009). For further background and input and output files, see Supplementary Text S1; Supplementary Fig. S1; Supplementary Table S1; and Supplementary Material S1.

Our understanding of the mutual range borders of the members of the smooth newt species complex has increased to such an extent that we feel confident in delineating the ranges for the individual species. We compose a distribution database for each individual species, focusing particularly on the regions where the different species come into contact: the Balkan Peninsula and the Carpathians. The vast range of $L$. vulgaris away from the contact zones with other species is already well covered by the New Atlas. The core of our database consists of localities, generally available at a high resolution, from 1) our own fieldwork, 2) museum collections, 3) the literature, and 4) online databases, and we augment our database with coarsegrained $(50 \times 50 \mathrm{~km})$ data from the New Atlas (see Supplementary Text S1 for further details). Our distribution database (5741 data points in total, 4177 newly collected and 1564 taken from the New Atlas) is visualized in Fig. 1 and is available online as Supplementary Table S2.

We follow Sillero et al. (2014a) and, based on our distribution database, produce atlas maps at a $50 \times 50 \mathrm{~km}$ UTM grid resolution for the five members of the smooth newt species complex occurring in the territory covered by the New Atlas (hence excluding L. kosswigi). Note that we completely remake the map for the Carpathian newt (the only member of the smooth newt species complex treated separately in the New Atlas). Compared to the New Atlas, we added 107 smooth newt grid cells and these were particularly positioned in the Balkans. An overview of the atlas maps is provided in Fig. 2, detailed maps can be found as 


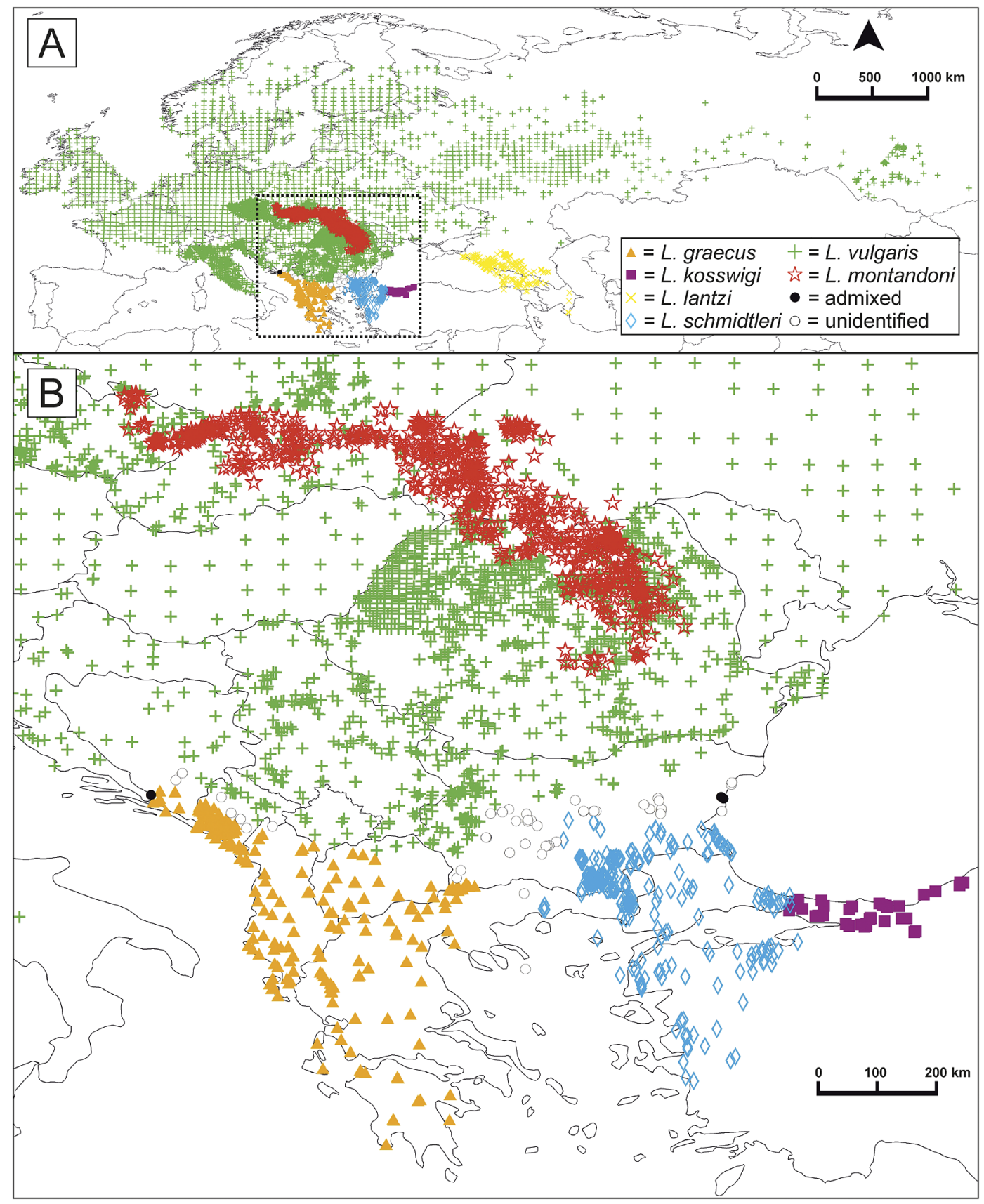

Figure 1. Distribution database for the six species constituting the smooth newt species complex (Lissotriton vulgaris sensu lato and L. montandoni). Raw data are provided in Supplementary Table S2. Data points are colour coded according to species (note that many L. vulgaris sensu stricto are obscured by L. montandoni dots). We highlight populations showing considerable genetic admixture. Populations for which no genetic or morphological data could be consulted were not identified to species. The boxed area in panel A is shown in more detail in panel B. 


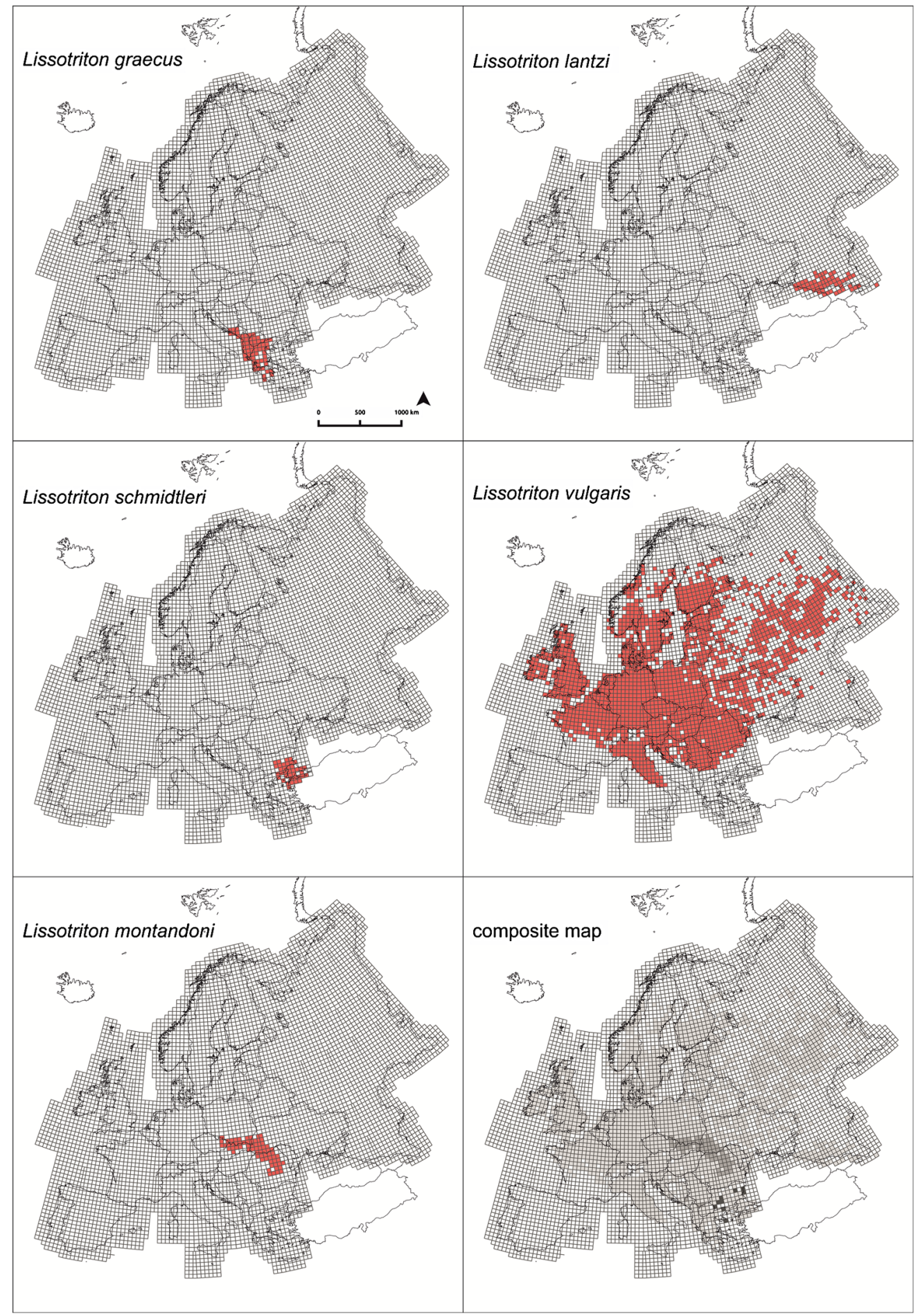

Figure 2. Distribution maps for the five members of the smooth newt species complex (Lissotriton vulgaris sensu lato and L. montandoni) in Europe, in the format of the New Atlas of Amphibians and Reptiles of Europe. The composite map shows how many species are present per grid cell, light filled grid cells reflecting the presence of a single and intermediate filled ones the presence of two species. Dark filled grid cells only contain smooth newt localities not identified to species.

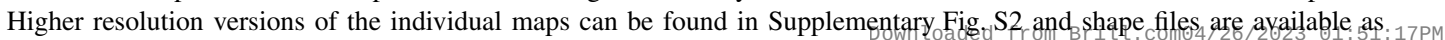
Supplementary Material S2. 
Supplementary Fig. S2 and shape files are included as Supplementary Material S2. Based on our dataset, we manage to present the latest insights on smooth newt distribution and identify key areas where more fieldwork is required. For instance, distribution limits between L. graecus and $L$. vulgaris are now much better understood, but the contact zone in central Montenegro (if any) requires further study. A particularly glaring gap in knowledge concerns the region where the ranges of $L$. vulgaris and $L$. graecus approach that of L. schmidtleri in Bulgaria and Greece.

In light of the taxonomic revision of the smooth newt species complex and the up to date distribution information collected here, we suggest that the IUCN status for the five species currently subsumed in L. vulgaris sensu lato should be revised (Arntzen et al., 2009). Inclusive taxa are likely to be more vulnerable than L. vulgaris sensu lato itself because of their considerably smaller distribution ranges. For example, L. kosswigi occurs in a densely populated area and has a very restricted distribution range (Wielstra et al., 2015), L. lantzi appears to have gone extinct in Turkey, Azerbaijan and Armenia (Skorinov et al., 2014), and L. graecus has been negatively affected by fish introductions, particularly in Montenegro (Denoël et al., 2009). A particular advantage of the open access of the New Atlas and the underlying data is that herpetologists can easily produce up to date atlas maps for the taxa they are working on (e.g. Wielstra et al., 2014). To facilitate future European mapping efforts, providing clear taxonomic justification, accurate estimates of distribution ranges and high-resolution distribution data is essential. For instance, the NA2RE project (Sillero et al., 2014b) aims at automatically centralizing data from local providers, whose effort will benefit from the availability of such information.

Acknowledgements. We are grateful to all our colleagues who contributed samples and distribution data over the years. Dan Cogălniceanu and Ruben Iosif provided data from their published database of Romanian amphibians in digital form. The Nature Conservation Agency of the Czech Republic provided data from their internal database. Permits for newt samples studied here for the first time were provided by: the Polish General Director for Environmental Protection (DOPozgiz-4200/II-78/3702/10/JRO); the National Academy of Sciences of Ukraine (03.04.12 No. 67); the Romanian Commission for Protection of Natural Monuments (3256/9.07.2010); the Italian Ministry of Environment (DPN-2009-0005106); the Environmental Protection Agency of Montenegro; the Ministry of Environment of Albania (Research Permit Request No. 6584); and TÜBITAK in Turkey. This project has received funding from the European Union's Horizon 2020 research and innovation programme under the Marie Skłodowska-Curie grant agreement No. 655487; the Fonds de la Recherche Scientifique - FNRS (J.0112.16), University of Liege (Fonds Speciaux pour la Recherche C-15/63); the Slovak Research and Development Agency under the contract no. APVV15-0147; the 'Ministero dell'Istruzione, dell'Università e della Ricerca' (PRIN project 2012FRHYRA); and the Polish National Science Centre grants 2012/04/A/NZ8/00662 to WB and $2014 / 15 / \mathrm{B} / \mathrm{NZ} 8 / 00250$ to PZ. MD is a Senior Research associate at Fonds de la Recherche Scientifique FNRS.

\section{References}

Alexander, D.H., Novembre, J., Lange, K. (2009): Fast model-based estimation of ancestry in unrelated individuals. Genome Res. 19: 1655-1664.

Arntzen, J.W., Kuzmin, S., Beebee, T., Papenfuss, T., Sparreboom, M., Ugurtas, I.H., Anderson, S., Anthony, B., Andreone, F., Tarkhnishvili, D., Ishchenko, V., Ananjeva, N., Orlov, N., Tuniyev, B. (2009): The IUCN Red List of Threatened Species 2009: e.T59481A11932252. DOI:10.2305/IUCN.UK.2009. RLTS.T59481A11932252.en. Downloaded on 17 May 2017.

Babik, W., Szymura, J.M., Rafiński, J. (2003): Nuclear markers, mitochondrial DNA and male secondary sexual traits variation in a newt hybrid zone (Triturus vulgaris $\times$ T. montandoni). Mol. Ecol. 12: 1913-1930.

Babik, W., Branicki, W., Crnobrnja-Isailovic, J., Cogalniceanu, D., Sas, I., Olgun, K., Poyarkov, N.A., GarciaParis, M., Arntzen, J.W. (2005): Phylogeography of two European newt species - discordance between mtDNA and morphology. Mol. Ecol. 14: 2475-2491.

Boulenger, G.A. (1880): Sur une forme intéressante de Triton provenant de Moldavie et observations sur le genre Pelonectes Lataste. Bull. Soc. Zool. Fr. 5: 37-40.

Denoël, M., Ficetola, G.F., Ćirović, R., Radović, D., Džukić, G., Kalezić, M.L., Vukov, T.D. (2009): A multi-scale approach to facultative paedomorphosis of European newts (Salamandridae) in the Montenegrin karst: distribution pattern, environmental variables, and conservation. Biol. Conserv. 142: 509-517.

Downloaded from Brill.com04/26/2023 01:51:17PM via free access 
Dubois, A., Raffaëlli, J. (2009): A new ergotaxonomy of the family Salamandridae Goldfuss, 1820 (Amphibia, Urodela). Alytes 26: 1-85.

Freytag, G.E. (1955): Ein neurer Teichmolch aus der Türkei. Zool. Anz. 154: 195-200.

Frost, D.R. (2013): Amphibian Species of the World: an Online Reference. Version 5.6 (9 January 2013). Electronic Database accessible at http://research.amnh.org/ herpetology/amphibia/index.html. American Museum of Natural History, New York, USA.

Kalezić, M.L. (1984): Evolutionary divergences in the smooth newt (Triturus vulgaris) (Urodela: Salamandridae): electrophoretic evidence. Amphib.-Reptil. 5: 221229.

Kalezić, M.L., Tucić, N. (1984): Genic diversity and population genetic structure of Triturus vulgaris (Urodela, Salamandridae). Evolution 38: 389-401.

Kalezić, M.L., Džukić, G., Crnobrnja Isailović, J., Tvrtković, N. (1987): On the Triturus vulgaris schreiberi problem: electrophoretic data. Alytes 6: 18-22.

Krizmanić, I., Mesaroš, G., Džukić, G., Kalezić, M.L. (1997): Morphology of the smooth newt (Triturus vulgaris) in former Yugoslavia: taxonomical implications and distribution patterns. Acta Zool. Acad. Sci. Hung. 43: $345-357$.

Linnaeus, C. (1758): Systema Naturae per Regna Tria Naturae, Secundum Classes, Ordines, Genera, Species, cum Characteribus, Differentiis, Synonymis, Locis. 10th Edition, Volume 1. L. Salvii, Stockholm, Sweden.

Nadachowska, K., Babik, W. (2009): Divergence in the face of gene flow: the case of two newts (Amphibia: Salamandridae). Mol. Biol. Evol. 26: 829-841.

Nadachowska-Brzyska, K., Zieliński, P., Radwan, J., Babik, W. (2012): Interspecific hybridization increases MHC class II diversity in two sister species of newts. Mol. Ecol. 21: 887-906.

Niedzicka, M., Fijarczyk, A., Dudek, K., Stuglik, M., Babik, W. (2016): Molecular inversion probes for targeted resequencing in non-model organisms. Sci. Rep. 6: 24051.

Pabijan, M., Zieliński, P., Dudek, K., Chloupek, M., Sotiropoulos, K., Liana, M., Babik, W. (2015): The dissection of a Pleistocene refugium: phylogeography of the smooth newt, Lissotriton vulgaris, in the Balkans. J. Biogeogr. 42: 671-683.

Pabijan, M., Zieliński, P., Dudek, K., Stuglik, M., Babik, W. (2017): Isolation and gene flow in a speciation continuum in newts. Mol. Phylogenet. Evol. 116: 1-12.

Rafiński, J., Cogălniceanu, D., Babik, W. (2001): Genetic differentiation of the two subspecies of the smooth newt inhabiting Romania, Triturus vulgaris vulgaris and $T$. v. ampelensis (Urodela, Salamandridae) as revealed by enzyme electrophoresis. Folia Biol. (Kraków) 49: 239245.

Raxworthy, C. (1988): A description and study of a new dwarf sub-species of smooth newt, Triturus vulgaris, from western Anatolia, Turkey. J. Zool. Lond. 215: 753763.

Raxworthy, C. (1990): A review of the smooth newt (Triturus vulgaris) subspecies, including and identification key. Herpetol. J. 1: 481-492.
Schmidtler, J.F., Franzen, M. (2004): Triturus vulgaris (Linnaeus, 1758) - teichmolch. In: Handbuch der Reptilien und Amphibien Europas. Schwanzlurche IIB, p. 847967. Grossenbacher, K., Thiesmeier, B., Eds, AulaVerlag, Wiesbaden.

Schmidtler, J.J., Schmidtler, J.F. (1983): Verbreitung, Ökologie und unterartliche Gliederung von Triturus vulgaris in der adriatischen Küstengebieten (Amphibia, Salamandridae). Spixiana 6: 229-249.

Sillero, N., Campos, J., Bonardi, A., Corti, C., Creemers, R., Crochet, P.-A., Crnobrnja Isailović, J., Denoël, M., Ficetola, G.F., Gonçalves, J., Kuzmin, S., Lymberakis, P., de Pous, P., Rodríguez, A., Sindaco, R., Speybroeck, J., Toxopeus, B., Vieites, D.R., Vences, M. (2014a): Updated distribution and biogeography of amphibians and reptiles of Europe. Amphib.-Reptil. 35: 1-31.

Sillero, N., Oliveira, M.A., Sousa, P., Sousa, F., GonçalvesSeco, L. (2014b): Distributed database system of the New Atlas of Amphibians and Reptiles in Europe: the NA2RE project. Amphib.-Reptil. 35: 33-39.

Skorinov, D., Litvinchuk, S., Borkin, L., Rosanov, J. (2008): Genetic differentiation, genome size and morphological variation in newts of the Lissotriton vulgaris group. In: Voprosy Gerpetologii, Proceedings of the Third Conference of Herpetological Society of AM Nikolsky, St. Petersburg, p. 363-371.

Skorinov, D., Litvinchuk, S., Borkin, L., Rosanov, J. (2011): Systematics of newts of the Lissotriton vulgaris complex (Salamandridae). In: Voprosy Gerpetologii, Proceedings of the Fourth Conference of Herpetological Society of AM Nikolsky, St. Petersburg.

Skorinov, D.V., Doronin, I.V., Kidov, A.A., Tuniev, B.S., Litvinchuk, S.N. (2014): Distribution and conservation status of the Caucasian newt, Lissotriton lantzi (Wolterstorff, 1914). Russ. J. Herpetol. 21: 251-268.

Speybroeck, J., Beukema, W., Crochet, P.-A. (2010): A tentative species list of the European herpetofauna (Amphibia and Reptilia) - an update. Zootaxa 2492: 1-27.

Tuniyev, B. (1999): A systematic list of amphibians from the alpides of the Caucasus and middle Asia, with comments on their taxonomy. Adv. Amphib. Res. Former Soviet Union 3: 43-75.

Wielstra, B., Sillero, N., Vörös, J., Arntzen, J.W. (2014): The distribution of the crested and marbled newt species (Amphibia: Salamandridae: Triturus) - an addition to the New Atlas of Amphibians and Reptiles of Europe. Amphib.-Reptil. 35: 376-381.

Wielstra, B., Bozkurt, E., Olgun, K. (2015): The distribution and taxonomy of Lissotriton newts (Amphibia, Salamandridae) in Turkey. ZooKeys 484: 11-23.

Wiens, J.J., Sparreboom, M., Arntzen, J.W. (2011): Crest evolution in newts: implications for reconstruction methods, sexual selection, phenotypic plasticity and the origin of novelties. J. Evol. Biol. 24: 2073-2086.

Wolterstorff, W. (1906): Über Triton vulgaris L. subsp. graeca Wolt. n. subsp. Zool. Anz. 29: 137-139.

Wolterstorff, W. (1914): Zwei neue Tritonformen der paläarktischen Region. Abhandlungen und Berichte aus dem Museum für Natur- und Heimatkunde zu Magdeburg 2: 371-381. 
Zavadil, V., Pialek, J., Dandova, R. (2003): Triturus montandoni (Boulenger, 1880) - Karpetenmolch. In: Handbuch der Reptilien und Amphibien Europas. Schwanzlurche IIA, p. 657-706. Grossenbacher, K., Thiesmeier, B., Eds, Aula-Verlag, Wiebelsheim.

Zieliński, P., Nadachowska-Brzyska, K., Wielstra, B., Szkotak, R., Covaciu-Marcov, S., Cogălniceanu, D., Babik, W. (2013): No evidence for nuclear introgression despite complete mtDNA replacement in the Carpathian newt (Lissotriton montandoni). Mol. Ecol. 22: 1884-1903.

Zieliński, P., Dudek, K., Stuglik, M.T., Liana, M., Babik, W. (2014a): Single nucleotide polymorphisms reveal genetic structuring of the Carpathian newt and provide evidence of interspecific gene flow in the nuclear genome. PLOS ONE 9: e97431.
Zieliński, P., Stuglik, M.T., Dudek, K., Konczal, M., Babik, W. (2014b): Development, validation and high throughput analysis of sequence markers in non-model species. Mol. Ecol. Resour. 14: 352-360.

Zieliński, P., Nadachowska-Brzyska, K., Dudek, K., Babik, W. (2016): Divergence history of the Carpathian and smooth newts modelled in space and time. Mol. Ecol. 25: 3912-3928.

Submitted: June 29, 2017. Final revision received: January 12, 2018. Accepted: January 31, 2018. Associate Editor: Gentile Francesco Ficetola. 